\title{
JŪRATÉ PAJĖDIENĖ
}

Lietuvių kalbos institutas

\section{PRITARIMAS PAŠNEKOVUI ŽEMAIČIŲ KASDIENYBĖS DISKURSE: FUNKCIJOS IR RAIŠKA (REMIANTIS XX A. II PUSĖS ŠALTINIAIS)}

\section{ANOTACIJA}

Straipsnyje pristatomas žvalgomasis tyrimas, kuriuo siekta nustatyti pritarimo pašnekovui raiškos elementus ir jų dažnumo pasiskirstymą trejopo pobūdžio žemaitiškame diskurse (įprastoje kalboje, naratyvuose ir telefoniniuose pokalbiuose). Tyrimui pasitelktas keliuose šaltiniuose paskelbtas XX a. II pusės šiaurès žemaičiu kalbẻjimo paveldas. Remiantis leksikografiniuose šaltiniuose (žr. Aleksandravičius 2011, Vanagienė 2014-2015) pateikta iliustracine medžiaga aptariamas subjektyviuoju vertinimu paremtas žemaičiams tinkamo bendravimo suvokimas, dažniausiai susijęs su darnos siekimu. Pritarimo raiškos elementų ir jų santykinio dažnumo pasiskirstymas realiame žemaičiu kalbèjime vertinamas analizuojant šiaurės žemaičių telšiškių autentiško kasdienybės kalbẻjimo tekstų rinkinio Taip šneka tirkšliškiai (žr. Girdenis 1996) duomenis.

ESMINIAI ŽODŽIAI: kasdieniška žemaičių kalba, spontaniškas dialogas, pritarimas pašnekovui, pakartojimas.

\section{IVADAS}

Žemaičių kaip etninès grupès buvimas pagrịstas kalbėjimosi, o ne rašymo patirtimi ${ }^{1}$. Lyginant sakytinès bendrinès lietuvių kalbos ir žemaitiško kalbejjimo ypatybes, pastarasis turi nemažai savitų bruožų, kurie sietini ir su fonologinėmis kalbinių sistemų diferenciacijomis, ir su skirtingais kultūriniais bendravimo modelių standartais, taip pat su nevienoda lietuvių ir žemaičių kalbų $^{2}$ sintaksinių struktūrų normiškumo samprata ${ }^{3}$. Šnekamosios bendrinès lietuvių kalbos tyrimai paprastai inicijuojami siekiant „statistiškai pagrịsti dažnai tik stebẻjimo būdu užfiksuotus šnekamosios ir rašytinès kalbos skirtumus“ (Dabašinskienė 2009: 14). Su stebèjimo būdu nustatytais žemaitiško ir lietuviško kalbinio bendravimo modelių raiškos skirtumais yra susijusi

1 Apie žemaičiuc kalbos rašto sistemos sukūrimo pastangas ir realijas žr. Pabrèža 2017.

${ }^{2}$ Apie kalbos ir dialekto skirtic ir kalbos kaip arealo, apimančio dialektų arealus, konceptą plg. Aliūkaitė 2013: 4; skirtingumu nuo bendrinès kalbos ir kitų tarmių grindžiamą žemaičių kalbos, apimančios ją sudarančias tarmes ir šnektas, suvokima žr. Pabrèža 2017: 47-48.

3 Šnekamajai kalbai būdingas struktūrinis savitumas nulemia jos tyrimų pobūdi ir iškelia specialius reikalavimus, tokius kaip būtinybẻ atsižvelgti i pokalbio situaciją, dalyvius, jų skaičių, temą ir kitus lingvistinius ir nelingvistinius požymius, plg. Dabašinskienė 2009: 14. 
ir čia pateikiamo žvalgomojo tyrimo idèja (rimtesne analize pagrịstas minėtų kalbinių sistemų sakytinių atmainų sugretinimas taip pat būtų gana sąlygiškas, nes turimi žemaičių kalbèjimo perrašai ir sakytinès (šnekamosios) ${ }^{4}$ bendrinès kalbos, reprezentuojančios privatųị bendravimo modelį, tekstai ${ }^{5}$ pristato skirtingo laikotarpio ir kalbejjimo situacijų pateiktis).

Straipsnyje siekiama apžvelgti vieną žemaitiškam dialogui būdingą ypatumą, greit pastebimą gimtakalbių bendrinès lietuvių kalbos vartotojų, tapusių žemaitiško pokalbio liudininkais, taip pat ryškiai krentančiu ị akis ir pažindinantis su autentiško žemaičių kasdienybės diskurso (ir dialogo, ir polilogo) perrašų tekstais. Tai pritarimo dialogo partneriui (ar partneriams) raiška ${ }^{6}$. Kasdieniškuose žemaičių pokalbiuose yra įprasta, kad pasyvią klausytojo poziciją užimantis diskurso dalyvis ị aktyvųji - kalbantị arba pasakojantį - diskurso narị reaguoja gana dažnu ir įvairiai išreikštu pritarimu. Ši diskurso ypatybè žemaičiams pakeitus kalbos kodą paprastai nebūna automatiškai perkeliama i bendrinę lietuvių kalbą. Kadangi tai nėra savaime išverčiama, tam tikrose situacijose šis pritarimas gali būti laikomas būtinu bendravimo kultūros elementu, kuriam bendrinejje kalboje žemaičiai tinkamo atitikmens neranda. Gali būti, kad bendraujant bendrine kalba būtent dèl tokių ar panašių kultūrinių skirtumų kylantis nesugebejjimas teisingai interpretuoti tylèjimą ar nežinojimas, kuo tinkamai pakeisti pauzes, žemaičiams kuria nejaukaus pokalbio įspūdị ir kartu stiprina tylenio žemaičio įvaizdį. Natūraliam bendrinès kalbos vartotojui tapus žemaitiško dialogo liudininku dažnai pasikartojanti ar nuolatinė pritarimo raiška atrodo kaip perteklinè ir verta pasišaipymo.

Dažną ir įvairiais būdais parodomą pritarimo pašnekovui raišką žemaitiškame diskurse galima sieti su stipriai išreiškiamu ir tradiciškai pageidaujamu komunikacinio tolygumo (plg. Edwards 2008: 335) siekimu arba trokštamo tarpasmeninio pripažinimo realizavimo modeliais (plg. Weigand 2010: 232), kurie susiję su mandagumo konkrečioje bendruomenèje supratimu ir takto principo realizacija. Pragmatika mandagumu leidžia aiškinti dvi prieštaringas tylëjimo implikacijas: priklausomai nuo pokalbio situacijos ir jo dalyvių sudèties tylëjimas gali būti suvokiamas ir kaip su tam tikru žemesniu (amžiaus, socialiniu) statusu susijusi pageidaujamo mandagumo raiška ir kaip savotiškas akibrokštas (plg. Leech 1999: 141). Iprasto pokalbio situacijose (kai dialogo, polilogo dalyvių socialinis statusas panašus, o bendravimas dažnas ir

${ }_{4}^{4}$ Apie sąvokų sakytine kalba ir šnekamoji kalba galimą sinonimiškumą ir skirti, kai sakytinè kalba suvokiama plačiau, o šnekamoji gali būti susiejama su buitiniu kalbos stiliumi žr. Nauckūnaitė 2003: 79-80; KamandulytėMerfeldienė 2014: 1.

${ }^{5}$ Pavyzdžiui, Sakytines lietuviu kalbos tekstyno dalies Spontanine privati kalba pateiktus duomenis galima vertinti kaip trumpas buitinio stiliaus kalbejimo atkarpas.

${ }^{6}$ Cia atsiribojama nuo prieštaravimo pašnekovui reakcijų raiškos. Apie pritarimo ir prieštaravimo ilokucinius aktus kaip susijusius su tam tikra pozicija pokalbyje (jie galimi tik kaip reakcija į prieš tai buvusi pašnekovo pasakymą) žr. Satkauskaitė 2011: 56-57.

${ }^{7}$ Apie vertikalųii (hierarchinị) ir horizontalųị socialinị nuotolị žr. Leech 1999: 126. 
pageidaujamas) poreikis vengti tylos ir palaikyti bendravimą su diskurso partneriu yra sietinas su bendruomenine - fatine - kalbos funkcija (žr. Leech 1999: 141). Dialogo teoretikè Edda Weigand, kalbą suvokianti kaip dialogą (žr. Weigand 2009), o dialogą - kaip ịvairiarūši žaidimą (žr. Weigand 2010), teigia, kad dialogu pagrịstas bendravimas realizuojamas remiantis tam tikrais vykdomaisiais principais, kuriuos kalbėtojas sąmoningai ar nesąmoningai pasirenka siekdamas ir pokalbị inicijuojančių, ir atliepimo reakcijų sąryšio, leidžiančių suvokti pokalbio visumą ir jame efektyviai dalyvauti (plg. Weigand 2010: 113). Būtent vykdomieji principai lemia dalyvavimo dialoge būdus ir gali tapti strategijomis (kai kalbėtojas siekia tam tikra linkme pasukti dialogo tèkmę). Tokios strategijos leidžia keisti pokalbio sekas, vertinimus ir emocijų raišką, leidžia kai ko išvengti ar kai ką pridengti arba atskleidžia kalbètojo norą bendradarbiauti ar priešintis (žr. Weigand 2010: 113, 118). Dialogo tèkmèje žmonès gali prisitaikyti prie pašnekovo (bendradarbiavimo strategija) arba pasirinkti susipriešinimą (konfrontacijos strategija), o kartais ir neutralią poziciją, dažniausiai sąmoningai to net nesuvokdami (Weigand 2010: 121-122). Su tokiu nesąmoningu prisitaikymo prie pašnekovo pasirinkimu ir malonumu dalyvauti bendrame pokalbyje tai parodant tam tikra reakcija labiausiai sietinas žemaitiškasis pritarimo raiškos modeliavimas, kai palankumas pašnekovui ir esamai pokalbio tèkmei gali būti išreiškiamas ne vien ịprastu teigiamu patvirtinimu ${ }^{8}$, bet ir tam tikrų pašnekovo frazių ar jų atkarpų kartojimu, parafrazėmis ar net ịsiterpimu ị konstruojamą sakinị, tai priimant kaip ịprasto (neįžeidžiančio) bendravimo normą.

Žemaitiškam dialogui būdingų pritarimo pašnekovui raiškos elementų įvairovè ir jų santykinis dažnumas (arba santykinis vartojimo pasiskirstymas tarpusavyje) žemaitiško pokalbio atmainose (dialoge ir poliloge) šiame straipsnyje aptariami remiantis keliuose šaltiniuose paskelbtu žemaitiško kalbẻjimo paveldu. Jị sudaro keli transkripcija užrašytieji natūralaus ir (ar) kiek išprovokuoto žemaitiško kalbėjimo(si) liudijimų sąvadai, fiksuojantys XX a. II pusės šiaurès žemaičių (telšiškių ir kretingiškių) ${ }^{9}$ kasdieniško kalbejjimo(si) situacijas. Pritarimo raiškai nagrinèti ypač parankūs knygoje Taip šneka tirkšliškiai: šiaurès žemaičiu telšiškiu tarmès tekstai su komentarais (Girdenis 1996, toliau - TŠT) esantys autentiški polilogo ir dialogo, reprezentuojamo telefoniniu pokalbiu, perrašai ${ }^{10}$. Žemaitišką tinkamo kalbejjimosi suvokimą

\footnotetext{
${ }^{8}$ Apie tai, kad bendradarbiavimas dialoge nebūtinai turi sutapti vien su îprastiniu teigiamu patvirtinimu, o konfrontacija - ne vien su negatyviu atsaku žr. Weigand 2010: 122.

${ }^{9}$ Apie žemaičių tarmès skirstymą ir šiaurès žemaičių kalbos ypatybes žr. Zinkevičius 1994: 85-87; apie esminį šiaurès žemaičių telšiškių skirtumą nuo kretingiškių, grindžiamą $u, i / / \rho, e$ kaita negalūniniuose skiemenyse, žr. Zinkevičius 1994: 114.

${ }^{10}$ Tarminių tekstų knygoje Taip šneka tirkšliškiai: šiaurès žemaičiu telšiškiu tarmès tekstai su komentarais pateikti 1968-1985 m. paslëptu mikrofonu įrašyti Mažeikių r. Tirkšlių apylinkejje gyvenusių Alekso Girdenio šeimynykščių ir kaimynų pokalbiai. Keli iš jų yra telefoniniai. Telefoninis pokalbis gali būti apibūdintas kaip nestandartinė bendravimo situacija (plg. Girdenis 1996: 142) dėl įvairių priežasčių (pvz., neįprastumo, susijusio su
} 
perteikiančių apibūdinimų esama Kretingos tarmès žodyne (Aleksandravičius 2011, toliau KTŽ $)^{11}$ ir Šiaurès vakaru žemaičiu žodyne: Ylakių, Lenkimu, Mosèdžio, Skuodo, Šačiu apylinkiu šnektos $A-O, P-Z ̌$ (Vanagienè, 2014-2015, toliau - ŠVŽŽ I, II) ${ }^{12}$. Labai svarbu pabrèžti, kad nurodytuose šaltiniuose pateikta iliustracinè medžiaga yra ir autentiška, ir labai tipiška. Ši autentiškumo ir tipiškumo darna leidžia iš žemaitiškos aplinkos išvykusiam žemaičiui, skaitančiam TŠT, KTŽ ar ŠVŽŽ, pasijusti tarsi sugrįžusiam ị praejjusị laiką.

Straipsnyje žemaitiško kalbėjimo frazès užrašytos siekiant kuo panašiau pakartoti šaltinių transkripciją (pasirinktuose šaltiniuose vartojami tam tikrais niuansais besiskiriantys užrašymo modeliai ${ }^{13}$ ) greta perrašo pateikiant transponavimui artimą žemaitiško kalbėjimo atkarpą bendrine kalba.

\section{PRITARIMO RAIŠKA ŽEMAIČIŲ KASDIENYBĖS PASIKALBĖJIMUOSE}

\section{Žemaitiškoji tinkamo kalbèjimo percepcija ir jos ugdymo modeliai}

Prieš pradedant nagrinèti pritarimo raiškos ypatybes žemaičių dialoge dera aptarti ir tai, koks pokalbis žemaičiams atrodo esąs tinkamas ${ }^{14}$. Paprastojo kalbos bendruomenès nario požiūris ${ }^{15}$ ì žemaičius gali būti prieštaringas, - jie gali būti vertinami kaip rèksmingi triukšmadariai arba kaip tyleniai. Taip prieštaringai vertinama greičiausiai dèl skirtingų kalbejimo(si) situacijų aplinkybių. Būnant kartu su saviškiais (kalbantis igimta (prigimta) kalba ${ }^{16}$ ) žemaičiams paprastai nebūdinga kalbèti nei tyliai, nei kultūringai ${ }^{17}$ (plg.: ka prãded vẹ̀s ${ }^{\grave{e}}$ laliete ,

negalëjimu pašnekovą vertinti vizualiai, ir dẻl būtinybès kalbèti itin aiškiai), bet būtent jame labai ryškiai atsiskleidžia pritarimo raiškos būtinumas, tikrame pokalbyje paprastai realizuojamas žvilgsniu, linkčiojimais, kurių negali užfiksuoti perrašas.

${ }^{11}$ KTŽ iliustracinei medžiagai būdingas dialogiškumu pasižymintis autentiškas šiaurès žemaičių kretingiškių kalbejjimas, žodyno sumanytojo kruopščiai užrašinėtas apie 60 metu (kartoteka rinkta nuo XX a. 5-ojo dešimtmečio vidurio iki 2004 m., o žodynas pradėtas rengti nuo 2006 m., plg. Aleksandravičius 2011: 4; Mikulènienė 2011: XII; Vaišnienė 2011: XX). Daugiau apie KTŽ teikiamos medžiagos interpretavimo galimybes žr. Pajẻdienė 2018b; 2019.

12 Šiame žodyne gausu ir kasdieniško žemaičių diskurso (1960-1990 m. Birutė Vanagienè nuolat užrašinėdavo savo artimiausios aplinkos pašnekesius), ir 1989-1996 m. vykusių dialektologinių ekspedicijų metu užfiksuotų pokalbių medžiagos (plg. Subačius 2014: XII; XIV-XVII), turinčios ir nemenką reprezentacinio kalbejimo sluoksni.

${ }^{13}$ Apie TŠT transkripciją žr. Girdenis 1996: 8-10; kiek išsamiau A. Girdenio vartotas transkripcijos modelis yra paaiškintas šiaurès žemaičių kalbejjimo perrašų sąvaduose Žemaičiu dzūkai ir Šiaurès žemaičiu Skuodo zona, žr. Girdenis 1996: 8-10; 2008: 17tt; 2012: 21tt; apie KTŽ - žr. Aleksandravičius 2011: 17-18, Vaišnienė 2011: XXIIIXXIX; apie ŠVŽŽ - žr. Vanagienè 2014: XXVIII.

14 Apie percepcinius tarminio kalbẻjimo tinkamumo modelius ir jų atpažinimą žr. Aliūkaitė 2019; Mikulènienè 2019.

${ }^{15}$ Apie bendrinės kalbos artefakto percepcija ir koncepcija pagrįstą tarminių ypatybių vertinimą žr. Aliūkaitė 2019: 87; apie paprastojo kalbos bendruomenès nario vertinimą kaip subjektyvųji tarmiškumą žr. Aliūkaitė 2019: $66,67$.

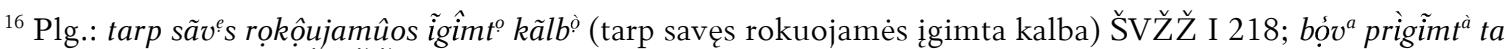
$k a \tilde{l} b^{\grave{a}}$ (buvo prigimta ta kalba) SVŽŽ I 186.

${ }^{17}$ Tai rodo ir TŠT paliktų (nekupiūruotų) drastiškų replikų (plg. Girdenis 1996: 8) gausa. 
negãl ni apsẹklausitt , kai pradeda visi lalèti, negal[ima] nei apsiklausyti‘ ŠVŽŽ I 369). Tylumą ar nekalbumą ${ }^{18}$ jie paprastai sieja su drovejjimusi ir buvimu neįprastoje aplinkoje, kurioje reikia nekasdieniškai elgtis ir kalbèti (dažniausiai negimtąja kalba). Todèl kalbėjimosi paprastumą ir sẻkmę žemaičiai linkę sieti su identišku savo ir kalbejjimo partnerio etniškumu (plg. pasakymą

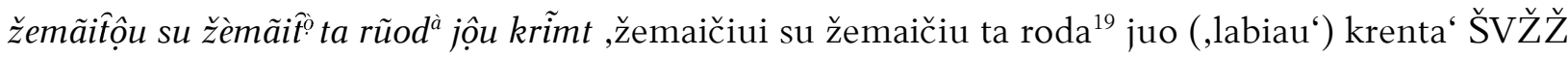
II 152). Kasdienybėje žemaičiai taip pat ne visada triukšmingi. Tam tikrose situacijose (pavyzdžiui, klausydami autoritetingo pasakotojo) jie gali būti itin tylūs, išskirtinai dèmesingi diskurso dalyviai. Ilgų pasakojimų klausytojo (klausytojų) dèmesingumą kaip sugebėjimą dalyvauti kito asmens pasakojime tylint rodo ir TŠT tekstai, kuriuose pateikiami trumpiniu M. pažymèti ilgi naratyvai ${ }^{20}$. Šis pasakojimo ir jo klausymo modelis atpažistamas kaip būdingas žemaitiškai aplinkai (tikètina, kad ne vien kaip buvęs, bet ir kaip vis dar esantis), kai vyriausias ar vyresnis autoritetingas pasakotojas (pavyzdžiui, motina, senelè, teta, ir gal kiek rečiau - tėvas, senelis, dėė) pasakoja praeities istorijas. Tokių pasakojimų klausomasi susikaupus ir tylint ${ }^{21}$. Beprasmį trukdymą draudžiančią nuostatą ir tylų dèmesingumą žemaičiai stengiasi ugdyti nuo mažens. Žemaitiško kasdienybės kalbejiimo atkarpas pateikiančiuose žodynuose taip pat esama frazių, kai vaikui draudžiama įsiterpti ị suaugusiųjų pokalbị ar jị pertraukti; panašios pastabos gali būti skirtos ir suaugusiems, pvz.:

(1) tabibúdâms krệtnešis/ nakệškis i_dẹdũju rũoda! // KTŽ 188 (tebebūdamas kritnešis nekiškis į didžiųjų rodą, kalbejjimąsi`)

(2) našmáiž̃ûokis i_dẹdũju târpa! // KTŽ 422 (nešmaižiokis ị didžiųių tarpą)

(3) no bet ka tọ̀ ũškiši, nèbišêit mûms nì kũok ${ }^{i}$ rũod $^{a}$ ŠVŽŽ I 308 (na, bet kai tu užkiši (,isiterpi $\left.{ }^{`}\right)$, nebeišeina mums nei kokia roda)

Kita vertus, tylèjimas taip pat gali būti vertinamas nepalankiai ir net prilyginamas neigalumui, pvz:

(4) a_nébelis èsì / ka_narọkọ́ujî̀s ẹ_nĩeka mộn nasakâ // KTŽ 253 (ar nebylys esi, kad nesirokuoji ir nieko man nesakai)

\footnotetext{
${ }^{18} \mathrm{Plg}$. frazèje nesaviškiui (iš kitos kalbinès aplinkos atėjusiam pašnekovui) adresuotą pasakymą mès nedẹdlê jãu rúodlĩve (mes nelabai jau rodlyvi ,kalbūs/šnekūs‘) ŠVŽŽ II 153.

${ }^{19}$ rodà (sl.) - ,šneka, pokalbis, pašnekesys‘ KTŽ 347.

${ }^{20}$ Tai Bronislavos Gedgaudaitès-Girdenienès pasakojimai, kurių paprastai nepertraukia, nesutrikdo jokia klausytojo (klausytojų) pastaba ar intarpas. Plg. TŠT pavadinimais Santuoka, mirtis, gyvenimas TŠT 95-105, Pakaruokliai, nekrikštai, vaikažudès TŠT 116-127 ir Ponai vargdieniai TŠT 155-163 įvardytų naratyvų vieninteli atlikèją.

${ }^{21}$ Šis modelis reprezentuoja minèto socialinio nuotolio dvejopą - horizontaliąią ir vertikaliąą - raišką.
} 
Minètuose šaltiniuose yra užfiksuota ir kitokių kalbejjimosi tinkamumo pateikčių, pavyzdžiui, reikalavimas dalyvaujant pokalbyje - kalbantis ir klausantis - žiūrèti pašnekovui i akis, plg.:

(5) rọkọ́udamûos veizîiek tệisềi_akis / vọ_nanairikis ì_šalis // KTŽ 249 (rokuodamasis $^{22}$ veizèk tiesiai i akis, o ne nairykisis ${ }^{23}$ i šalis)

(6) sọ̀_anộu rũodas naẹšvési / ànũo nãirĩmûos vệns // KTŽ 249 (su anuo (,juo') rodos neišvesi, [iš] ano nairymasis ${ }^{24}$ vienas)

(7) rọkọ́ujẹntệis rẽk ì_akis veizietẹ / vọ_na_žvalôitệis //KTŽ 348 (rokuojantis reikia ị akis veizèti, o ne žvalgytis)

Žodine tradicija pagristos bendruomenès nariams susikalbëjimas yra svarbiausias tarpusavio susižinojimo būdas, todèl nuo mažens ugdomos nuostatos, reikalaujant ne vien aiškios ir tinkamos artikuliacijos (žr. 8-10 pavyzdžius), bet ir atidos kalbejjimo turiniui, reikšmei ir nuotaikai (žr. 11-16 pavyzdžius), plg.:

(8) kúo_tọ n̂âzgi / rọkộukis kãp žmúogọ̀s // KTŽ 256 (ko tu niauzgi, rokuokis kaip žmogus)

(9) sakîk âiškê, nemormîek ŠVŽŽ I 455 (sakyk aiškiai, nemurmèk)

(10) kúo_tọ pọrslúojîis / ka_pàsakûoji? // KTŽ 327 (ko tu purslojies ${ }^{25}$, kai pasakoji)

(11) kúo_tọ̀čè úomâuji tûok̂us niekùs! // KTŽ 265 (ko tu čia omauji ${ }^{26}$ tokius niekus)

(12) tọ_žèbelûoji tûok̂us niekùs / papàsakûok kũ_nûors rîmta // KTŽ 497 (tu žebelioji tokius niekus, papasakok ką nors rimto)

(13) natarškiek nĩeku // KTŽ 441 (netarškèk niekų)

(14) ni ruodas / ni pasakas su tou makalu // KTŽ 224 (nei rodos, nei pasakos su tuo makalu)

(15) sọ̀_pejuokọ̀ káp_dọrnọ̀ / nẽ rũodas / nẽ pásakas // KTŽ 347 (su pijoku kaip [su] durnu nei rodos, nei pasakos)

(16) kú_tọ_plûmpi niekùs/ gèrãu papàsakûok / kãp gívenì // KTŽ 308 (ką tu pliumpi niekus, geriau papasakok, kaip gyveni)

\footnotetext{
22 Plg. rokãvimos (hibr.) - ,kalbėjimasis‘ KTŽ 347.

${ }^{23}$ nairýties, naĩros, naĩres - ,sukinètis, dairytis iš paniūrų, padilbų‘ KTŽ 249.

${ }^{24}$ naĩrymos - ,sukinèjimasis, dairymasis‘ KTŽ 249.

${ }^{25}$ purslóti, ója, óje - ,taškyti seilèmis‘ KTŽ 327.

${ }^{26}$ ómauti, auja, $\sim$ avo - ,nesąmones kalbėti, rèkauti‘ KTŽ 265.
} 
Tyrimui pasirinktuose šaltiniuose esantys autopercepciniai patvirtinimai rodo, kad žemaičiai savąii išskirtinumą grindžia kalbos ir papročių savitumu. Ta igimtoji (prigimtoji) žemaičių kalba gali būti apibūdinama kaip negraži, bet vis dẻlto švari, pasižyminti aiškiu ir lengvu tarimu (plg. frazę nèra prisvilusi), pvz.:

(17) no žemãitê - kãalbà skệras, pàprotẽ skệras ŠVŽŽ II 20 (na, žemaičiai - kalba skiriasi, papročiai skiriasi)

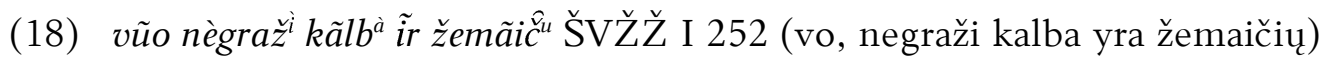

(19) žemãitu kálbà nĩer pisvẹ́lọsi // KTŽ 403 (žemaičių kalba nėra p[r]isvilusi)

Žemaičiai savąij (etniniu požiūriu) kalbėiimą dažnai sieja su tiesmukiškumu kaip norma (plg. sakyti stačiai, pakrauti - ,išsakyti tiesiai į akis'), plg.:

(20) žemãitê sáka stàtê / pakrâun / ẹg ganà // KTŽ 389 (žemaičiai sako stačiai, pakrauna ir gana)

Vis tik asmeniškuose pasisakymuose stengiamasi išryškinti kieno nors priešgyniavimą ir tiesmukiškumą kaip netinkamas savybes, todèl asmenis, beatodairiškai įrodinėjančius savo tiesą, mègstama apibūdinti kaip nenuovokius bei nesukalbamus ir pabrèžiama, kad reikia sugebėti sutarti su kitu asmeniu, plg.:

(21) ộns nì kuok̂ũos nùvûokas natộr rọkọ́udamûos sọ̀ žmuogọ̀ / tùjãu ižeidẹnie / priš̀ingàujẹs // KTŽ 263 (ans nei kokios nuvokos neturi rokuodamasis su žmogu[mi], tu[o]jau ižzeidinè[ja], priešingiaujasi)

(22) jê nûori / rọkộukis kãp žmúogọs / vọ_nakàbẹnîekis // KTŽ 137 (jei nori, rokuokis kaip žmogus, o ne kabinèkis)

(23) sọ̣naravọ žmúogọ̀ ni_pasệrọộusi dúorã / ni_sọsẹtãrsi // KTŽ 251 (su naravu ${ }^{27}$ žmogu[mi] nei pasirokuosi dorai, nei susitarsi)

(24) àš ni_sọ_vệinọ žmúogọ̀ nanûorọ prệklītệis// KTŽ 320 (aš nei su vienu žmogumi nenoriu priklytis ${ }^{28}$ )

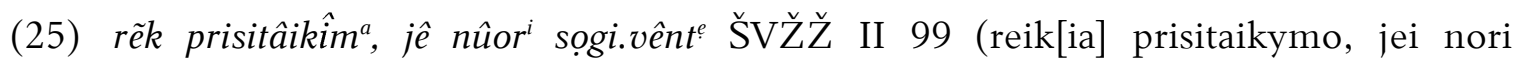
sugyventi)

27 narãvas, $\sim a ̀$ (sl.) - ,užsispyręs, greit susierzinąs’ KTŽ 251.

${ }^{28}$ priklytis, ijas, ijès (sl.) - ,bartis, pyktis, kitiems trukdyti' KTŽ 320. 
Ne vien deklaruojamos nuostatos, bet ir pati kalbejimosi maniera rodo, kad vienas iš paprasčiausių būdų atskleisti savo palankumą dialogo partneriui yra kalbant būti dèmesingam ir tai parodyti įvairiais būdais išreiškiamu pritarimu.

\section{Pritarimo įprastiniame kasdienybės diskurse raiška}

İprastame dialoge, kai pašnekovas yra prieš akis, pritarimo jam raiška gali būti paprastesnè: tam užtenka dėmesingumo, parodomo nuolatiniu akių kontaktu ir tam tikra - neatsainia, bet ir neužgožiančia - kūno laikysena bei linktelejjimu ar santūriu gestikuliavimu. Žemaitiško kalbėjimo atkarpų sąvaduose galima rasti tam tikrų užuominų apie tokio pritarimo realizavimo būdus ir jų reikšmes, pvz.:

(26) àš, sãk ${ }^{a}$, bepakinknûojau, bet àš <..> nĩek nesak̂âu ŠVŽŽ I 303 (aš, sako, bepakinknojau (,tik palinkčiojau'), bet aš $<\ldots>$ nieko nesakiau)

(27) jê kinknûoji gâlva / ẹšêt / ka_sọttinkì // KTŽ 162 (jei kinknoji galva, išeit, kad sutinki)

(28) túolãu stuoviédâms ộns mộn mírktẹliejẹ // ẹr_aš_vẹskû sọpratâu // KTŽ 239 (toliau stovėdamas ans man mirktelejjo, ir aš viską supratau)

(29) pamuosẹkáva sọ̀_rọkọ̀ ẹ_viél sọsệệitẹ i_kamūlâti // KTŽ 242 (pamosikavo su ranka ir vèl susirietė ì kamuolaitị)

Leksikografiniuose žemaičių kalbẻjimo šaltiniuose yra užfiksuota ir įgarsintos - žodinès - pritarimo raiškos elementų. Dažniausiai tai trumpos pritarimo ištaros, kai tas pats elementas pakartojamas vieną ar daug kartų. Pavyzdžiui, pašnekovo teiginių propoziciniam turiniui patvirtinti ir paties pasakojimo tęstinumui skatinti gali būti vartojamos ,taip, taigi“ reikšmę turinčios dalelytès ahà, jè, jẽ்; jó (plg. ahà KTŽ 22; ŠVŽŽ I 3; jè arba jè jè KTŽ 131, jie, jĩe ŠVŽŽ I 235; jó KTŽ 132), pritarimo raiškos jaustukai ái, nù (ái ŠVŽŽ I 3; nọ̀; nọ nọ̀ ŠVŽŽ I 477; KTŽ 261), patvirtinimo reikšmès prieveiksmiai áiškiai (âiškê ŠVŽŽ I 4), tikraĩ (tẹ̀krã ŠVŽŽ II 343) ir kiti panašūs su pokalbio koordinavimu turinio ir ritmiškumo aspektais susiję kalbos vienetai, plg.:

(30) jó / tẽp e creêkies padarite // KTŽ 132 (jo, taip ir reikès padaryti)

(31) jie jie, vãsara ${ }^{a}$ lãik ̣̂̀ nie tẽe(p) blúogã //ŠVŽŽ I 235 (jè jè, vasaros laike nèr taip blogai)

(32) ái, bộva gèrũ žĩdu, àmện! ŠVŽŽ I 3 (ai, buvo gerų žydų, amen (,labai‘)!)

(33) nọ nọ, ka.p tìk jọ̀dộm pačọmiero ŠVŽŽ I 477 (no no, kap tik judum (,judviem‘) pačiu mieru (,pats tas')) 
Ištisinio žemaitiško diskurso pateikčių sąvado Taip šneka tirkšliškiai tekstai rodo, kad iprastame žemaičių diskurse pritariama ne vien šią reikšmę turinčiais žodeliais (jaustukais, dalelytėmis, prieveiksmiais), bet ir pakartojant tam tikras pašnekovo sakinių ar frazių atkarpas ar jas parafrazuojant, plg.:

(34) V. nọjug_tẹikt tèrẽkı žvírblienê // sakîst jau_kããtst ĩ.rt / adbiẹg(a) jau / pàsı_mùn ${ }^{(i)} / /$ M. nọi_nộiๆ //TŠT 77 (V. Nu juk tiek tereik Žvirblienei, sakys jau kaltas yr[a] - atbėgo jau pas mane. M. Nui nui.)

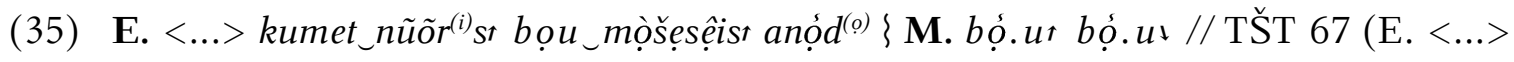
kuomet nors buvo mušęsi anuodu. M. Buvo buvo.)

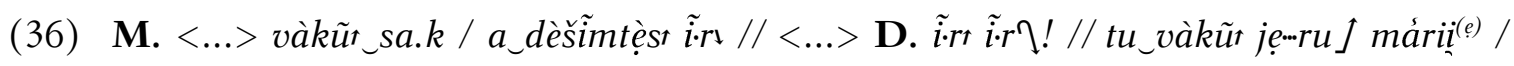

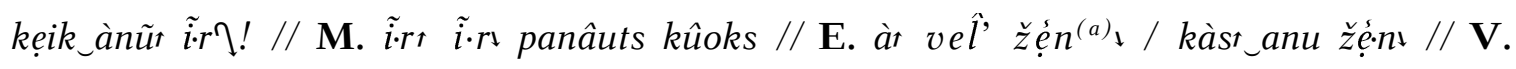

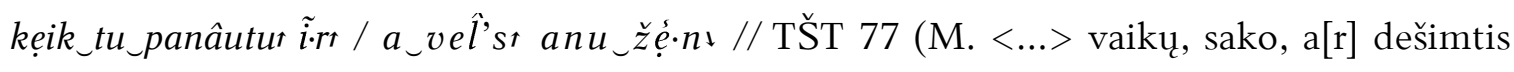
yr[a] <..> D. Yr[a] yr[a]! Tų vaikų, Jèr[a]u Marija, kiek anų yr[a]! M. Yr[a] ir panautas (,mergautinis') koks. E. O vel[nias] žino, kas aną žin[o]. V. Kiek tų panautų yr[a], o velnias aną žino.)

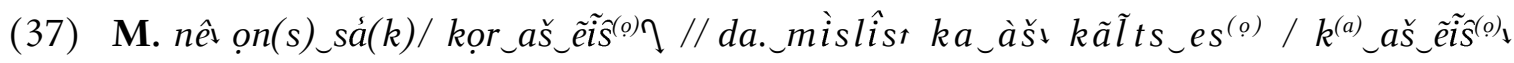
//V. aíškêๆ! // paŝk̂u_pagalwûost / kad àš kã̃ ts! // TŠT 77 (M. Ne, an(s) sako, kur aš eisiu, dar mislys, kad aš kaltas esu, kai aš eisiu. V. Aiškiai! Paskui pagalvos, kad aš kaltas.)

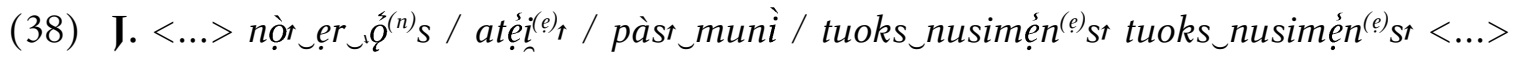

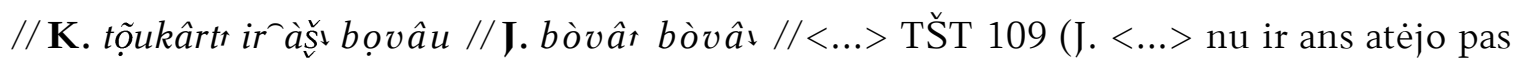
mane, toks nusiminęs, toks nusiminęs $<\ldots>$ K. Tuokart ir aš buvau. J. Buvai buvai $<\ldots>$ )

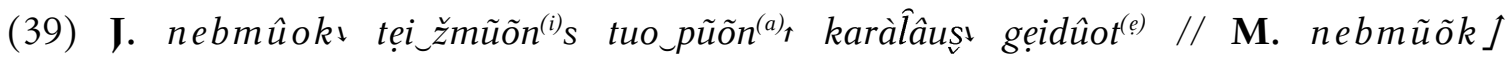

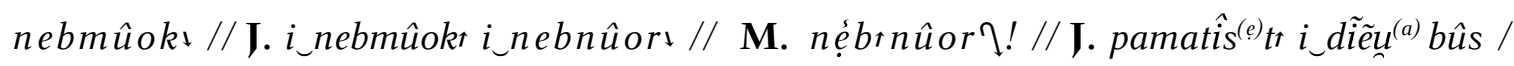
báusmiẽ̃̃ šimệt // M. jệt jẹ̀ı // TŠT 110 (J. Neb[e]moka tie žmonys to Pono Karaliaus giedoti. M. Nebemoka, nebemoka. J. Ir nebemoka, ir nebenori. M. Nebenori! J. Pamatysit ir Dievo bus bausmè šimet. M. Jè jè.)

Kartais kartojant pašnekovo frazės atkarpą būna sukuriami ir ne visai standartinio modelio - dvigubos autorystės ${ }^{29}$ - sakiniai, kai kartojamos frazės dalimi ką tik klausytoju buvęs diskurso dalyvis įsiveržia ị pašnekovo sakinio struktūrą, plg.:

${ }^{29}$ Daugiau apie tokius sakinius žr. Pajėdienè (2018a: 94). 


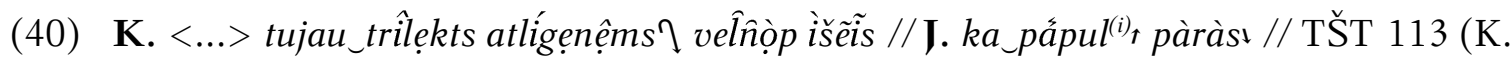
$<\ldots>$ tuojau tryliktas atlyginimas velniop išeis, J. kai papuoli paras (,gauni parų [nuovadoj atbūt $\left.]^{`}\right)$.)

Paprastai toks kalbėjimosi būdas priimamas kaip norma, o iš šono atrodo tartum žaidimas, kai pašnekovai vienas kitam perduoda kalbėjimo iniciatyvą kurdami pasakojimą iš dèliojamų trumpų frazių. İdomu, kad vieno pokalbio dalyvio tariamo sudètinio sakinio struktūrą suardžius pašnekovo intarpu, pavyzdžiui, specialiai siekiant pabrèžti nuostabą sukèlusio fakto trukmę, pirmasis kalbètojas gali ramiai tęsti pasakojimą apibūdindamas veiksmo ribą ir pasiektą rezultatą, o kartu ir gramatiškai užbaigdamas sakinị, plg.:

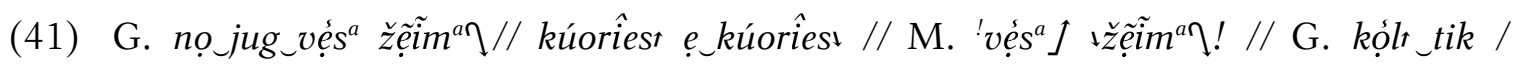
isẹkûorẹı// TŠT 202 (G. Na juk visą žiemą korèsi ir korèsi (,prašèsi ir prašèsi'), M. Visą žiemą! G. kol tik įsikore (,ịsiprašè‘).)

1-oje lenteleje pateikti duomenys rodo, kad ịprastame kasdienybės dialoge ar didesnès grupès pokalbyje žemaičiai pritarimą pašnekovui dažniausiai parodo kartodami tam tikrą ką tik kalbėjusio pašnekovo frazės dalį ar parafrazuodami jo pasakymą. Tokie atvejai sudaro vidutiniškai $\sim 65$ proc. bendros pritarimo pasirinktuose TŠT poliloguose raiškos. Palyginti dažnai pritarimui pasirenkami ir teigiamieji trumpieji patvirtinimai vienkartiniais ar su pakartojimu išsakomais jee, jie ir no, noi, noje tipų žodeliais (bendras santykinis jų vartojimo dažnumas atitinkamai yra $\sim 15$ proc. ir $\sim 9$ proc.).

1 LENTELE். Absoliutus ir santykinis pritarimo elementų dažnumas trijuose TŠT poliloguose Supjaustè Žvirbli, p. 66-81, Alu geria, p. 81-95, Girtuokliams beveik geriau, p. 105-116

\begin{tabular}{|c|c|c|c|c|c|c|c|c|}
\hline & \multicolumn{2}{|c|}{ 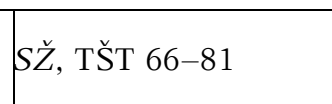 } & \multicolumn{2}{|c|}{ Ag, TŠT 81-95 } & \multicolumn{2}{|c|}{ Gbg, TŠT 105-116 } & \multicolumn{2}{|c|}{$\begin{array}{l}S Z ̌, A g, G b g \\
\text { pokalbiuose }\end{array}$} \\
\hline $\begin{array}{l}\text { Pritarimo raiškos } \\
\text { elementai }\end{array}$ & $\begin{array}{l}\text { Kiekis } \\
\text { vienetais }\end{array}$ & $\begin{array}{l}\text { Santykinis } \\
\text { dažnu- } \\
\text { mas }\end{array}$ & $\begin{array}{l}\text { Kiekis } \\
\text { vienetais }\end{array}$ & $\begin{array}{l}\text { Santykinis } \\
\text { dažnu- } \\
\text { mas }\end{array}$ & $\begin{array}{l}\text { Kiekis } \\
\text { vienetais }\end{array}$ & $\begin{array}{l}\text { Santykinis } \\
\text { dažnu- } \\
\text { mas }\end{array}$ & $\begin{array}{l}\text { Kiekis } \\
\text { vienetais }\end{array}$ & $\begin{array}{l}\text { Santykinis } \\
\text { dažnu- } \\
\text { mas }\end{array}$ \\
\hline aha; $a$ & 2 & $2 \%$ & 3 & $4 \%$ & - & - & 5 & $2 \%$ \\
\hline$j e ; j i e$ & 12 & $14 \%$ & 11 & $14 \%$ & 8 & $19 \%$ & 31 & $15 \%$ \\
\hline$m h m ; m$ & 2 & $2 \%$ & 2 & $2 \%$ & 1 & $2 \%$ & 5 & $2 \%$ \\
\hline nо; поі; поје & 6 & $7 \%$ & 11 & $14 \%$ & 2 & $5 \%$ & 19 & $9 \%$ \\
\hline ne & 2 & $2 \%$ & 2 & $2 \%$ & - & - & 4 & $2 \%$ \\
\hline
\end{tabular}




\begin{tabular}{|l|l|l|l|l|l|l|l|l|}
\hline tep tep & 2 & $2 \%$ & 1 & $1 \%$ & - & - & 3 & $2 \%$ \\
\hline aiško; aiške & 4 & $5 \%$ & 2 & $2 \%$ & - & - & 6 & $3 \%$ \\
\hline $\begin{array}{l}\text { Pašnekovo frazės } \\
\text { pakartojimas } \\
\text { (parafrazè) }\end{array}$ & 58 & $\mathbf{6 6} \%$ & 49 & $\mathbf{6 1} \%$ & 31 & $\mathbf{7 4} \%$ & 138 & $\mathbf{6 5} \%$ \\
\hline Iš viso & 88 & $100 \%$ & 81 & $100 \%$ & 42 & $100 \%$ & 211 & $\mathbf{1 0 0} \%$ \\
\hline
\end{tabular}

\section{Pritarimo nestandartinèse privataus bendravimo situacijose raiška}

Ryškiausios žemaičių pritariamosios (palaikomosios) diskurso reakcijos telefoninio pokalbio su ipprastu pašnekovu atvejais ${ }^{30}$. Tokiose vis tik nestandartiškumu pasižyminčiose bendravimo situacijose ${ }^{31}$ pritarimo raiškos elementų vartojama gausiau nei įprastai greičiausiai dèl to, kad ịprastus tinkamo bendravimo elementus - tylųi klausytojo atidumą ir vizualųi dèmesingumą - telefoniniame pokalbyje žemaičiai siekia pakeisti igarsintais pritarimo elementais, prilygstančiais darnos su pašnekovu akivaizdumo pateiktims. Pritarimo raiška priklausomai nuo konteksto gali būti įvairi (ir net neiginio dalelyčių formos, žr. 43-iame pavyzdyje esančią ne ne samplaiką ir jos pavartojimo aplinką), plg.:

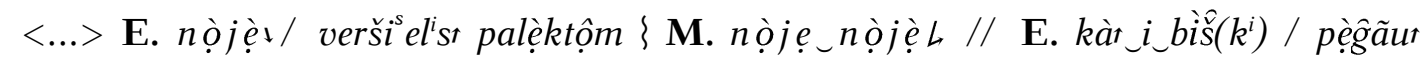

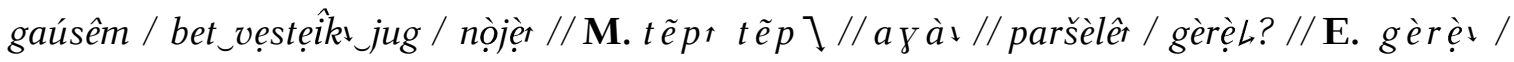

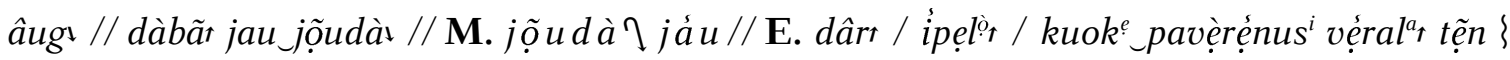

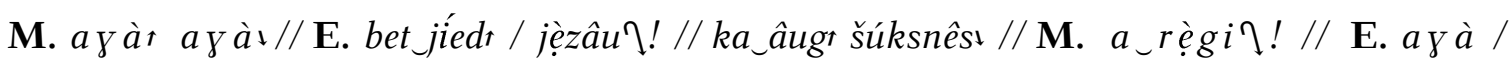
<..> TŠT $181(<\ldots>$ E. Nujè, veršelis paliktu. M. Nuje nujè. E. Kad ir biški pigiau gausim, bet vistiek juk, nujè. M. Tep tep, aha. Paršeliai geri? E. Geri, auga dabar jau juodai (,gerai/ labai‘). M. Juodai jau. E. Dar ịpilu kokio pavirinusi viralo ten. M. Aha aha. E. Bet èda, Jėzau! Kad auga šūksniais M. Ar regi! E. Aha. <..>)

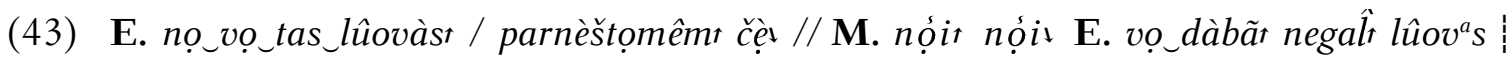

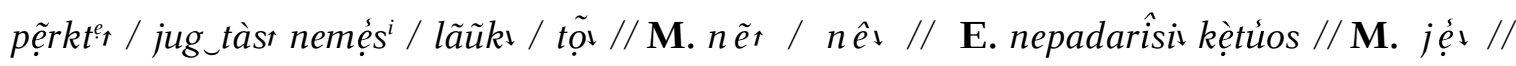
E. nội / léit paŝuntàsı // M. jẹ̀ı// TŠT 179 (E. Na, o tas lovas perneštume čia. M. Nui nui. E. O dabar negal[i] lovos pirkti, juk tas nemesi lauk, tą. M. Ne ne. E. Nepadarysi kitos. M. Je. E. Nui, lai pasiuntas (,tebūnie`). M. Jè.)

30 Čia nestandartine privataus bendravimo situacija laikomi labai artimos aplinkos pašnekovų (pavyzdžiui, mamos ir dukros) telefoniniai pokalbiai.

${ }^{31}$ Dèl pokalbių situaciju standartiškumo dar žr. 10 išnašą. 
TŠT pateiktuose trijų telefoninių pokalbiu perrašuose (žr. Pavasariop TŠT 137-146, Gripas ir kiti negeri dalykai TŠT 177-184 ir Bronele mire TŠT 277-281) dviejų pašnekovu pritarimo vienas kitam raiška yra intensyvesnè ir kitokia, nei TŠT esančių ịprastų dialogu ir grupinių pokalbių perrašuose (plg. 1-oje ir 2-oje lentelèse pateiktus duomenis). Iš TŠT telefoninių pokalbių tekstuose esančių pritarimo elementų kiekybinès analizės matyti, kad iprastųjų pritarimo reikšmès žodelių ir pašnekovo ištarto diskurso frazių dalies pakartojimo (kartu su parafrazėmis) santykinis dažnumas pasiskirsto gana panašiai visuose trijuose pokalbiuose. Iprastame taikiame (nekonfliktiniame) žemaitiškame pokalbyje reakcija ị kalbèjimą dažniau būna išreikšta tam tikros pašnekovo frazès dalies pakartojimu ar parafraze (tokie vienetai sudaro $\sim 65$ proc. bendros pritarimo rodiklių raiškos), o telefoniniame pokalbyje pašnekovui pritariama, jis paskatinamas, parodoma, kad jis girdimas ir suprantamas, pateikiant trumpąsias teigiamo patvirtinimo nuorodas. Jos pasirinktų pokalbių perrašuose sudaro $\sim 78$ proc. visos ịgarsinto pritarimo raiškos (grupès asmenų pokalbiuose trumposios pritarimo fiksacijos sudaro $\sim 35$ proc.) . Vertinant santykini pritarimo raiškos elementų pasiskirstymą tirtuose telefoniniuose pokalbiuose matyti, kad žemaitiškame dialoge ipprasčiausia pašnekovui pritarti trumpaisiais triju tipu patvirtinimo reikšmès žodeliais no; noi; noje ( 20 proc.), aha; a; ai ( 20 proc. ) ir je; jie; ëje; ajei $(\sim 17$ proc. ), kurie gali būti išsakomi ir kaip pavieniai elementai, ir kaip dvigubos ar trigubos samplaikos. Labai panašiu santykiniu dažnumu (nuo 21 proc. iki 24 proc.) tirtuose telefoninių pokalbių tekstuose buvo pritariama pakartojant tam tikros pašnekovo frazės dalį. Tyrimas rodo, kad pati kalbejjimo situacija taip pat gali paveikti pritarimo raiškos dažnumą. Palyginus konkrečius pritarimo raiškos pavartojimo skaičius matyti, kad su stresine situacija susijusiame pokalbyje, kai gaunama ypač nauja ir netikèta informacija (žr. pokalbio Bronele miré, TŠT 277-281 duomenis), pritarimo pašnekovui raiškos vienetų vartojama ženkliai mažiau nei įprastame pašnekesyje.

2 LENTELĖ. Absoliutus ir santykinis pritarimo elementų dažnumas trijuose telefoniniuose TŠT pokalbiuose Pavasariop, p. 137-146, Gripas ir kiti negeri dalykai, p. 177-184, Bronele mire, p. $277-281$

\begin{tabular}{|c|c|c|c|c|c|c|c|c|c|}
\hline & & $\begin{array}{l}\text { Pavasario } \\
137-146\end{array}$ & $p, \quad$ TŠT & $\begin{array}{l}\text { Gripas ir } \\
\text { dalykai, } \\
\text { TŠT 177-1 }\end{array}$ & $\begin{array}{ll} & \text { kiti negeri } \\
84 & \end{array}$ & $\begin{array}{l}\text { Bronele mi } \\
\text { TŠT 277- }\end{array}$ & & Trijuose p & kalbiuose \\
\hline $\begin{array}{l}\text { Pritarimo } \\
\text { elementai }\end{array}$ & raiškos & $\begin{array}{l}\text { Kiekis } \\
\text { vienetais }\end{array}$ & $\begin{array}{l}\text { Santykinis } \\
\text { dažnu- } \\
\text { mas }\end{array}$ & $\begin{array}{l}\text { Kiekis } \\
\text { vienetais }\end{array}$ & $\begin{array}{l}\text { Santykinis } \\
\text { dažnu- } \\
\text { mas }\end{array}$ & $\begin{array}{l}\text { Kiekis } \\
\text { vienetais }\end{array}$ & $\begin{array}{l}\text { Santykinis } \\
\text { dažnu- } \\
\text { mas }\end{array}$ & $\begin{array}{l}\text { Kiekis } \\
\text { vienetais }\end{array}$ & $\begin{array}{l}\text { Santykinis } \\
\text { dažnu- } \\
\text { mas }\end{array}$ \\
\hline$a h a ; a ; a i$ & & 25 & $22 \%$ & 31 & $24 \%$ & 6 & $9 \%$ & 62 & $20 \%$ \\
\hline$\dot{e} ; \dot{e} h \dot{e}$ & & 4 & $4 \%$ & 3 & $2 \%$ & 3 & $5 \%$ & 10 & $3 \%$ \\
\hline
\end{tabular}




\begin{tabular}{|c|c|c|c|c|c|c|c|c|}
\hline$j e ;$ jie; ёje; ajei & 13 & $12 \%$ & 24 & $19 \%$ & 14 & $21 \%$ & 51 & $17 \%$ \\
\hline jo jo & - & - & 1 & $1 \%$ & - & - & 1 & $1 \%$ \\
\hline $\begin{array}{l}\text { eik eik; eik to; to } \\
\text { pamislyk }\end{array}$ & 3 & $3 \%$ & 3 & $2 \%$ & 3 & $5 \%$ & 9 & $3 \%$ \\
\hline mata; a regi!; veiziek & 3 & $3 \%$ & 4 & $3 \%$ & & & 7 & $2 \%$ \\
\hline$m h m ; m$ & 2 & $2 \%$ & 1 & $1 \%$ & 1 & $1 \%$ & 4 & $1 \%$ \\
\hline no; noi; појё & 19 & $17 \%$ & 19 & $15 \%$ & 24 & $37 \%$ & 62 & $20 \%$ \\
\hline ne ne; ne & - & - & 2 & $1 \%$ & - & - & 2 & $1 \%$ \\
\hline tep tep & 6 & $5 \%$ & 5 & $4 \%$ & - & - & 11 & $4 \%$ \\
\hline va; vo; vuo & 9 & $8 \%$ & 9 & $7 \%$ & - & - & 18 & $6 \%$ \\
\hline $\begin{array}{ll}\text { Pašnekovo } & \text { frazès } \\
\text { pakartojimas } & \\
\text { (parafrazė) } & \end{array}$ & 27 & $24 \%$ & 27 & $21 \%$ & 14 & $22 \%$ & 68 & $22 \%$ \\
\hline Iš viso & 111 & $100 \%$ & 129 & $100 \%$ & 65 & $100 \%$ & 305 & $100 \%$ \\
\hline
\end{tabular}

\section{APIBENDRINIMAS}

Žemaitiškame tarpusavio bendravime vieno pašnekovo pritarimas kitam kalbejjimo turinio ir (ar) emocinio palaikymo atžvilgiu labiausiai susijęs su įprastumu ir bendruomenine - fatine kalbos funkcija. Tyrimui pasirinktų autentiško žemaitiško kalbejjimo atkarpų sąvadų, fiksuojančių XX amžiaus II pusès žemaičių kalbą, teikiama medžiaga rodo bendravimo tinkamumo sąsają su pašnekovui rodomu palankumu (jei tik leidžia bendravimo situacija ir turinys).

Derama dėmesingumo raiška siejama su universaliomis tinkamo (taktiško) bendravimo nuostatomis, kurios realizuojamos ramia kūno laikysena, akių kontaktu, atidumu pašnekovo elgesiui ir kalbejjimo turiniui. Palankumą pašnekovo kalbejjimo turiniui ir pateikimo būdui žemaičiai yra linkę suvokti kaip mandagumą ir tai stengiasi parodyti ịvairia pritarimo raiška.

Autentiško žemaičių kalbėjimo tekstų rinkinyje Taip šneka tirkšliškiai esančių trejopo pobūdžio diskursų analizè rodo skirtingas klausytojo pritarimo kalbančiajam asmeniui praktikas. Tikros ar išgalvotos, bet įdomios istorijos pasakojimas paprastai nesulaukia garsiniu klausytojo intarpų. Iprastame kelių asmenų pokalbyje vieno pašnekovo pritarimas kitam (naują informaciją pateikiančiam) dažniau išreiškiamas pašnekovo frazės ar jos dalies pakartojimu ar parafraze ( 65 proc.) nei patvirtinimo reikšmės žodeliais ( 35 proc.). Telefoniniuose pokalbiuose žymiai dažniau vartojama pritarimo pašnekovui elementų, o tai siejama su vizualios pašnekovo 
įvertinimo galimybės stoka. Tirtuose telefoniniuose pokalbiuose pritarimas palyginti dažniau buvo išreikštas įvairiomis variacijomis ir moduliacijomis tariamais patvirtinimo reikšmès žodeliais ( $\sim 78$ proc.) nei pakartojant pašnekovo frazes ( 22 proc.).

\section{ŠALTINIAI}

Aleksandravičius J. 2011: Kretingos tarmès žodynas, sudarè Danguolè Mikulènienè, Daiva Vaišnienè. Vilnius: Lietuvių kalbos institutas.

Girdenis A. 1996: Taip šneka tirkšliškiai: šiaurès žemaičiu telšiškių tarmès tekstai su komentarais.

Vilnius: Mokslo ir enciklopedijų leidykla.

Sakytinès lietuvių kalbos tekstynas ${ }^{32}$. Prieiga internete: http://sakytinistekstynas.vdu.lt.

Vanagienè B. 2014-2015: Šiaurès vakarų žemaičių žodynas. Ylakių, Lenkimu, Mosèdžio, Skuodo,

Šačiu apylinkių šnektos, A-O; P-Ž, Vilnius: Lietuvių kalbos institutas.

\section{LITERATŪRA}

Aliūkaitė D. 2013: Horinzontalusis ir vertikalusis kalbos kontinuumo skaidumas: XXI amžiaus kalbèjimo variantai paprastojo kalbos vertintojo požiūriu. - Taikomoji kalbotyra 2, 1-27. Prieiga internete: https://taikomojikalbotyra.lt/ojs/index.php/taikomojikalbotyra/article/view/23/14.

Aliūkaitė D. 2019: Objektyvusis tarmiškumas: požymiai ir vertė. - Respectus Philologicus 35 (40), 63-91.

Dabašinskienė I. 2009: Šnekamosios lietuvių kalbos morfologinès ypatybès. - Acta Linguistica Lithuanica 60, 1-15.

Girdenis A., 2008: Pratarmè. Ivvadas. - Girdenis A., sud., Žemaičiu dzūkai. Tekstai su komentarais. Vilnius: Mokslo ir enciklopediju leidybos institutas, 10-32.

Girdenis A., 2012: Pratarmè. Itvadas. - Girdenis A., sud., Šiaurès žemaičiu Skuodo zona. Tekstai su komentarais. Vilnius: Vilniaus universiteto leidykla, 13-38.

32 Morfologiškai anotuotas Vytauto Didžiojo universitete kaupiamas sakytinės lietuvių kalbos tekstynas, kurio kūrimą rèmė Lietuvos valstybinis mokslo ir studiju fondas (2006-2008 m.), Lietuvos mokslo taryba pagal Nacionalinę lituanistikos plètros 2009-2015 m. programą (LIT-9-11) ir pagal Valstybinę lituanistinių tyrimų ir sklaidos 2016-2024 metų programą (LIP085/2016). 
Edwards J. A. 2008: The Transcription of Discourse. - Deborah Schiffrin, Deborah Tannen, Heidi E. Hamilton, eds., The Handbook of Discourse Analysis, Blackwell Publishing, $321-348$.

Kamandulytè-Merfeldienė L. 2014: Pertarų dažnumas ir įvairovè sakytinèje lietuvių kalboje.

- Bendriné kalba 87, 1-10. Prieiga internete: www.bendrinekalba.lt.

Leech G. 1999: Principles of Pragmatics. London, New York: Longman.

Mikulènienė D. 2011: Juozo Aleksandravičiaus lituanistinè ir pedagoginè veikla. - Kretingos tarmès žodynas, autorius Juozas Aleksandravičius, sudare Danguolè Mikulėnienė, Daiva Vaišnienè. Vilnius: Lietuvių kalbos institutas, VII-XII.

Mikulènienė D. 2019: Tarmiškumo bruožų nomenklatūra: nuo tarminių požymių prie tarmiškumo žymenų. - Respectus Philologicus 35(40), 51-62.

Nauckūnaitė Z. 2003: Loginiai ir lingvistiniai sakytinès ir rašytinès raiškos skirtumai. - Žmogus ir žodis: didaktine lingvistika $5,78-83$.

Pabrèža J. 2017: Žemaičių kalba ir rašyba, Šiauliai: Šiaulių universiteto leidybos skyrius.

Pajėdienè J. 2018a: Santykinio laiko raiška prieveiksminiais laiko sakiniais šiaurès žemaičių telšiškių tarmèje. - Baltu filologíija 27(1/2), 75-100.

Pajèdienė J. 2018b: Žemaitiškos tapatybès raiška: dèlionė iš Kretingos tarmès žodyno (2011) pavyzdžių. - Acta Linguistica Lithuanica 79, 64-104.

Pajèdienè J. 2019: Kretingos tarmès žodyne (2011) atsiskleidžiantys žemaitiško emocinio lauko kontūrai. - Acta Linguistica Lithuanica 80, 80-108.

Satkauskaitė D. 2011: Lingvistinè pragmatika. Mokomoji knyga aukštujų mokyklu studentams.

Kaunas. Prieiga internete:

https://www.knf.vu.lt/dokumentai/failai/katedru/germanu/Satkauskaite_LINGVISTINE _PRAGMATIKA_elektronine.pdf.

Subačius G. 2014: Birutės Rokaitės-Vanagienės žodynas ir kiti darbai. - Vanagienė Birutė, 2014: Šiaurès vakarų žemaičiu žodynas. Ylakiu, Lenkimu, Mosèdžio, Skuodo, Šačių apylinkiu šnektos, A-O, Vilnius: Lietuvių kalbos institutas, XI-XII.

Vaišnienè D. 2011: „Kretingos tarmès žodynas“: pagrindiniai medžiagos pateikimo principai.

- Kretingos tarmés žodynas, autorius Juozas Aleksandravičius, sudarè Danguolè Mikulėniené, Daiva Vaišnienè. Vilnius: Lietuvių kalbos institutas, XX-XXXVI.

Weigand E. 2009: Language as Dialogue, Amsterdam / Philadelphia: John Benjamins Publisching Company.

Weigand E. 2010: Dialogue - The Mixed Game, Amsterdam / Philadelphia: John Benjamins Publisching Company. 
JŪRATĖ PAJĖDIENĖ. Pritarimas pašnekovui žemaičių kasdienybės diskurse: funkcijos ir raiška

Zinkevičius Z.1994: Lietuvių kalbos dialektologija. Vilnius: Mokslo ir enciklopedijų leidykla.

Gauta 20191210

Priimta 20191230 


\section{AGREEMENT WITH INTERLOCUTOR IN SAMOGITIAN DAILY DISCOURSE: FUNCTIONS AND EXPRESSION (BASED ON THE SOURCES \\ OF THE $2^{\mathrm{ND}}$ HALF OF THE $20^{\mathrm{TH}}$ CENTURY)}

\section{Summary}

In the context of Samogitian interpersonal communication one interlocutor's agreement with another in terms of the content of speaking and/or emotional support is mostly concerned with familiarity and the social - phatic - function of language. The study made use of the collections that record the Samogitian language of the $2^{\text {nd }}$ half of the $20^{\text {th }}$ century. The material provided by the collections of passages illustrating Samogitian authentic speaking shows the link between the appropriateness of communication and the favourable attitude towards the interlocutor (if permitted by a communicative situation and content). The proper expression of attentiveness is associated with the universal attitudes of appropriate (tactful) communication, which are realized by a calm body posture, eye contact, attention to the interlocutor's behaviour, and the content of speaking. Samogitians tend to perceive the favourable approach towards the interlocutor's content of speaking and its way of presentation as politeness and try to show it by varied expression of agreement.

The analysis of the discourses of three types contained in the collection of texts illustrating Samogitian authentic speaking Taip šneka tirkšliškiai (cf. Girdenis 1996) reveals different practices of the listener's agreement with the speaker. The narration of a true or fictitious but interesting story is usually not interrupted by the listener. In a usual conversation of several individuals the agreement of one interlocutor with another (providing new information) is more commonly expressed by the repetition of the interlocutor's phrase or its part ( $65 \%)$ rather than the short words expressing agreement $(\sim 35 \%)$. The structure of phone conversations demonstrates a considerably more frequent usage of elements of agreement with the interlocutor, which is explained by the inability of the interlocutor's visual evaluation. In the phone conversations under analysis agreement was relatively more commonly expressed by the short words of agreement, which were pronounced by utilizing different voice modulations $(\sim 78 \%)$, compared to the repetition of the interlocutor's phrases $(\sim 22 \%)$. 
JŪRATĖ PAJĖDIENĖ. Pritarimas pašnekovui žemaičių kasdienybės diskurse: funkcijos ir raiška

KEYWORDS: Samogitian daily language, spontaneous dialogue, agreement with the interlocutor, repetition.

JŪRATÉ PAJÉDIENÉ

Lietuvių kalbos institutas

Petro Vileišio g. 5, LT-10308 Vilnius jurate.pajediene@lki.lt 